\title{
Hubungan Aktivitas Fisik dengan Indeks Massa Tubuh (IMT) pada Siswa SMP Negeri 1 Padang
}

\author{
Lastri Daniati ${ }^{1}$, Afriwardi $^{2}$, IImiawati $^{3}$ \\ ${ }^{1}$ Fakultas Kedokteran Universitas Andalas Padang \\ ${ }^{2}$ Bagian Fisiologi Fakultas Kedokteran Universitas Andalas, Padang \\ ${ }^{3}$ Bagian Farmakologi Fakultas Kedokteran Universitas Andalas, Padang
}

\begin{abstract}
A B S T R A C T
Latar Belakang. Kesehatan seluruh kelompok usia termasuk usia remaja dipengaruhi oleh tingkat aktivitas fisik dari seseorang. Individu yang memiliki aktivitas fisik yang tinggi biasanya memiliki indeks massa tubuh (IMT) yang normal.

Objektif. Mengetahui hubungan tingkat aktivitas fisik dengan IMT pada siswa SMP Negeri 1 Padang.

Metode. Penelitian ini merupakan studi cross sectional pada siswa SMP (50 laki-laki dan 102 perempuan). Penelitian ini dilakukan pada bulan Maret 2020. Berat badan dan tinggi badan diukur, IMT dihitung dan dibagi menjadi IMT normal/ kurang dan lebih. Tingkat aktivitas fisik diwawancarai menggunakan kuesioner indeks Baecke dan dibagi menjadi tingkat aktivitas fisik rendah dan sedang. Data dianalisis menggunakan uji Chi square dan hasil bermakna signifikan bila

Result. Most students had normal or low BMI (64.5\%) and had a low physical activity level (59.9\%). There was a significant correlation between physical activity level and BMI $(P=0.03)$. Conclusion. It can be concluded that the physical activity level and BMI are associated with students of SMP Negeri 1 Padang.

Keywords: adolescent; body mass index; physical activity

\section{Apa yang sudah diketahui tentang topik ini?}

Aktivitas fisik merupakan salah satu faktor yang mempengaruhi status gizi. Semakin ringan intensitas aktivitas fisik yang dilakukan maka berpengaruh terhadap status gizi (IMT/U) lebih bahkan obesitas.
\end{abstract} $p$-value $<0,05$.

Hasil. Sebagian besar siswa memiliki IMT normal/ kurang $(64,5 \%)$ dan memiliki tingkat aktivitas fisik ringan (59,9\%). Terdapat hubungan signifikan antara tingkat aktivitas fisik dan IMT $(p=0,03)$.

Kesimpulan. Tingkat aktivitas fisik dan IMT adalah berhubungan pada siswa di SMP Negeri 1 Padang.

Kata kunci: remaja, indeks massa tubuh, aktivitas fisik

Background. The health of people including adolescents is influenced by the level of physical activity of a person. An individual with a high physical activity level usually has a normal body mass index (BMI).

Objective. To determine the association of physical activity level and BMI in students of SMP Negeri 1 Padang.

Method. This research was a cross-sectional study of 152 junior high school students (50 males and 102 females). The survey was conducted in March 2020. Bodyweight and height were measured, BMI was calculated and classified into normal/ low and high BMI. The level of physical activity was evaluated by using the Baecke index questionnaire and classified into low and moderate activity levels. Data were analyzed by using the Chi-square test and the result was considered significant at $p$ value $<0.05$.

\section{Apa yang ditambahkan pada studi ini?}

Penggolongan status IMT dibagi menjadi dua yaitu gizi normal/ kurang dan gizi lebih dengan berpedoman pada Peraturan Menteri Kesehatan Republik Indonesia No 2 Tahun 2020.

\section{CORRESPONDING AUTHOR}

\section{Name: Lastri Daniati}

Phone: +6282384885116

E-mail: lastridaniati31@gmail.com

\section{ARTICLE INFORMATION}

Received: September $23^{\text {rd }}$, 2020

Revised: October $15^{\text {th }}, 2020$

Available online: October $31^{s t}, 2020$ 


\section{Pendahuluan}

Pengukuran antropometri adalah bagian dari pemeriksaan klinis yang paling sering digunakan untuk mengidentifikasi status gizi. Ada empat variabel yang biasa digunakan dalam pengukuran ini yaitu berat badan, usia, jenis kelamin dan tinggi badan. Pengukuran antropometri meliputi pengukuran berat badan, tinggi badan, lipatan kulit dan lingkar berbagai bagian tubuh. ${ }^{1}$

Pengukuran tinggi badan dan berat badan dapat digunakan untuk menentukan Indeks Massa Tubuh (IMT). IMT merupakan indikator yang mudah dan sering digunakan untuk menentukan status gizi. Angka IMT dapat diperoleh dari membagi berat badan dengan tinggi badan kuadrat. Batas IMT orang dewasa berbeda dengan anak-anak. Pada anak-anak (IMT menurut usia) dibedakan berdasarkan jenis kelamin karena pertumbuhan keduanya berbeda. IMT menurut usia dan jenis kelamin digunakan pada anak-anak usia 2-20 tahun yang kemudian dimasukkan pada grafik. IMT bermanfaat untuk mengetahui tingkat populasi berat badan lebih dan obesitas. ${ }^{2}$

Nilai IMT yang tinggi menunjukkan bahwa mereka kelebihan berat badan atau obesitas. Mereka memiliki kesempatan yang lebih besar untuk terkena penyakit seperti hipertensi, kolesterol, diabetes tipe 2, penyakit jantung, stroke dan kanker. IMT yang lebih dari normal juga memiliki peningkatan risiko kematian dini. Semakin meningkatnya skor IMT seseorang, maka risiko terhadap kesehatannya juga akan meningkat. ${ }^{3}$

Kejadian overweight dan obesitas pada remaja berhubungan langsung dengan depresi dan citra tubuh yang buruk sedangkan secara tidak langsung berkaitan dengan penilaian diri yang negatif, gangguan makan dan kualitas hidup yang lebih buruk. $^{4}$ Obesitas pada remaja mengakibatkan biaya medis dan sosial yang sangat besar. Di Amerika Utara biaya medis yang dikeluarkan mencapai US\$ 209,7 miliar. Jika biaya yang dikeluarkan untuk obesitas tetap konstan dan tidak meningkat dari 2010-2030, pengeluaran medis dapat hemat mencapai US\$ 549,5 miliar. $^{5}$

Menurut data National Health and Nutrition Examination Survey (NHANES) tahun 2015-2016 di Amerika Serikat, prevalensi obesitas pada remaja sebesar 18,5\%. Prevalensi obesitas pada usia 6-11 tahun sebanyak $18,4 \%$ dan $20,6 \%$ di usia 12-19 tahun. ${ }^{6}$ Penelitian yang dilakukan di
Brazil, menemukan obesitas sebanyak 10,4\% (Selatan) pada usia 6-18 tahun, 15,4\% (Tenggara) pada usia 2-19 tahun dan 4,3\% (Timur Laut) pada usia 6-19 tahun. ${ }^{7}$ Penelitian dengan 30.145 sampel di lima negara Association of Southeast Asian Nation (ASEAN) (Indonesia, Laos, Filipina, Thailand dan Timor-Leste) tahun 2015, pada usia rata-rata 14 tahun menemukan prevalensi obesitas (14\%), underweight $(8,7 \%)$ dan normal $(77,3 \%) .8$

Data survey Riset Kesehatan Dasar (Riskesdas) tahun 2018, angka kejadian indeks massa tubuh berdasarkan umur (IMT/U) pada remaja usia 1315 tahun di Indonesia sebesar 6,8\% (kurus), 75,3\% (normal), 11,2\% (gemuk) dan 4,8\% (obesitas). Prevalensi pada laki-laki sebesar 8,9\% (kurus), 72,3\% (normal), 10,7\% (gemuk) dan $5,3 \%$ (obesitas) dan perempuan 4,5\% (kurus), $78,6 \%$ (normal), $11,7 \%$ (gemuk) dan 4,3\% (obesitas). Berdasarkan tempat tinggal yaitu perkotaan sebanyak 6,8\% (kurus), 73,2\% (normal), 12,3\% (gemuk) dan 5,9\% (obesitas) dan di pedesaan 6,8\% (kurus), 77,7\% (normal), 10\% (gemuk) dan 3,6\% (obesitas). Pada Sumatera Barat sebesar 6,0\% (kurus), 77,3\% (normal), $10,3 \%$ (gemuk) dan $4,3 \%$ (obesitas). ${ }^{9}$

Menurut Putra (2016) yang melakukan penelitian pada siswa kelas VII- IX di SMPN 1 Padang mendapatkan IMT pada kategori normal sebesar 61\%, kategori kurus sebesar 35\% dan kategori gemuk sebesar 3,9\%.10 Menurut Premayani (2014) yang melakukan penelitian pada remaja di SMP Santo Yoseph Denpasar mendapatkan hasil bahwa terdapat hubungan antara aktivitas fisik dengan status gizi remaja di SMP Santo Yoseph Denpasar. Tingkat aktivitas fisik tergolong sangat ringan sebanyak $60,4 \%$, tergolong ringan sebanyak $25,5 \%$ dan sisanya tergolong sedang sedangkan $40,6 \%$ remaja memiliki IMT normal, 16\% kurus, 42,5\% gemuk dan $0,9 \%$ obesitas. ${ }^{11}$ Masalah status gizi ini, dapat diukur menggunakan IMT. ${ }^{12}$

IMT dihitung dengan cara berat badan dalam satuan kilogram $(\mathrm{kg})$ dibagi dengan kuadrat tinggi badan dalam satuan meter (m). Pengukuran IMT dinilai murah dan mudah untuk melakukan skrining dalam mengkategorikan berat badan. IMT memiliki keterbatasan yaitu tidak dapat mengukur bayi usia kurang dari dua tahun, wanita hamil dan olahragawan. Hal ini disebabkan karena 
IMT tidak bisa membedakan antara massa lemak dengan massa otot atau cairan. ${ }^{12}$

Interpretasi IMT pada anak-anak tidak sama dengan IMT pada dewasa. Penentuan status gizi untuk anak-anak dilakukan dengan mengukur berat badan menurut panjang badan atau tinggi badan (BB/PB atau BB/TB). Hasil pengukuran dimasukkan ke dalam grafik pertumbuhan World Health Organization (WHO) 2006 dan Center for Disease Control and Prevention (CDC) 2000. Grafik pertumbuhan WHO 2006 digunakan untuk anak usia 0-5 tahun sedangkan grafik CDC 2000 digunakan untuk anak usia 5-18 tahun. ${ }^{13}$

Faktor yang mempengaruhi IMT secara langsung seperti usia, genetik dan jenis kelamin sedangkan secara tidak langsung seperti pola makan, faktor lingkungan, faktor psikis, faktor kemajuan teknologi dan aktivitas fisik. ${ }^{14}$ Salah satu cara untuk menghambat angka overweight dan obesitas yang terjadi sejak dini adalah rutin melakukan aktivitas fisik. Istilah aktivitas fisik berbeda dari olahraga. Aktivitas fisik merupakan gerakan tubuh yang disebabkan oleh aksi otot yang meningkatkan pengeluaran energi sedangkan istilah olahraga digunakan saat gerakannya direncanakan, terarah dan terstruktur. ${ }^{15}$

Anak-anak dan remaja usia 6-17 tahun direkomendasikan harus melakukan aktivitas fisik sedang sampai kuat selama 60 menit setiap hari. Rekomendasi menekankan bahwa bergerak lebih banyak dan sedikit duduk. Jenis aktivitas fisik yaitu aktivitas aerobik (seperti bersepeda atau jalan cepat), aktivitas penguatan otot (seperti latihan angkat berat) dan aktivitas penguatan tulang (seperti lompat tali atau lari). Berdasarkan pedoman aktivitas fisik Amerika, remaja dan orang dewasa di Amerika Serikat yang tidak cukup aktif terdapat $80 \% .{ }^{16}$ Pada penduduk Indonesia yang kurang melakukan aktivitas fisik pada usia $\geq 10$ tahun sebesar $33,5 \% .{ }^{9}$

Lokasi penelitian akan dilakukan di SMPN 1 Padang. SMP ini merupakan sekolah negeri dan termasuk salah satu SMP favorit di Kota Padang. Penelitian yang dilakukan di sekolah negeri, antusias siswanya lebih tinggi terutama jika ada informasi di bidang kesehatan. Biasanya sekolah negeri secara langsung menerapkan informasi yang diberikan di lingkungan sekolah. Mereka juga dapat memberikan penyuluhan secara preventif kepada teman-teman dan masyarakat sekitar.

Berdasarkan uraian diatas, maka penulis merasa perlu untuk meneliti hubungan aktivitas fisik dengan IMT pada siswa SMPN 1 Padang.

\section{Metode}

Jenis penelitian ini adalah penelitian observasional analitik dengan rancangan penelitian cross sectional. Penelitian ini bertujuan untuk mengetahui hubungan tingkat aktivitas fisik dengan IMT pada siswa SMPN 1 Padang. Penelitian dilakukan di SMPN 1 Padang pada bulan September 2019 sampai dengan Juli 2020. Populasi penelitian adalah siswa SMPN 1 Padang. SMP Negeri 1 Padang memiliki 24 kelas. Jumlah siswa di kelas VII sebanyak 288 orang, kelas VIII 224 orang dan kelas IX 256 orang. Total siswa SMPN 1 Padang berjumlah 768 orang. Besar sampel penelitian sebanyak 152 orang.

Teknik pengambilan sampel siswa menggunakan teknik stratified random sampling berdasarkan tingkat kelas. Kriteria inklusi yaitu bersedia menjadi responden. Kriteria eksklusi yaitu menderita penyakit yang mempengaruhi berat badan (Diabetes melitus, penyakit tiroid, penyakit jantung dan tuberkulosis).

\section{Hasil}

Penelitian dilaksanakan di SMPN 1 Padang yang terletak di Jl. Jend. Sudirman No. 3, Kota Padang. Penelitian dilakukan selama 5 hari dengan rincian penelitian dilakukan pada hari Jumat, 6 Maret 2020 diperoleh 40 orang responden, kemudian dilanjutkan pada hari Senin, 9 Maret 2020 diperoleh 30 responden dan pada hari Rabu sampai Jumat, tanggal 18- 20 Maret 2020 diperoleh 82 responden. Terdapat 24 kelas di SMPN 1 Padang yaitu VII A- I, VIII A-G dan IX AH. Penelitian dilakukan pada jam istirahat, selasela pergantian jam pelajaran dan kelas yang gurunya tidak hadir. Peneliti mengajak teman dari pendidikan dokter sebanyak 4 orang untuk membantu peneliti selama penelitian.

Peneliti menggunakan timbangan digital untuk mengukur BB, microtoise untuk mengukur TB dan kuesioner indeks Baecke untuk menilai aktivitas fisik. Responden penelitian adalah siswa kelas VII, VIII dan IX di SMPN 1 Padang. Jumlah total populasi adalah 768 orang. Peneliti melakukan pengambilan sampel dengan cara masuk ke semua 
kelas kemudian memilih beberapa siswa dengan mengacak nomor absen nanti diambil 6 atau 7 orang tiap lokal untuk melakukan pengukuran berat badan, tinggi badan dan mengisi kuesioner.

Tabel 1. Analisis Univariat

\begin{tabular}{lcc}
\hline \multicolumn{1}{c}{ Karakteristik Responden } & f & $\mathbf{\%}$ \\
\hline Kelas & & \\
VII & 57 & 37,5 \\
VIII & 44 & 28,9 \\
IX & 51 & 33,6 \\
Jenis Kelamin & & \\
$\quad$ Laki-laki & 50 & 32,9 \\
$\quad$ Perempuan & 102 & 67,1 \\
Usia & & \\
13 & 46 & 30,3 \\
14 & 55 & 36,2 \\
15 & 51 & 33,6 \\
IMT & & \\
$\quad$ Gizi normal/kurang & 126 & 82,9 \\
$\quad$ Gizi lebih & 26 & 17,1 \\
Aktivitas fisik & & \\
$\quad$ Ringan & 91 & 59,9 \\
$\quad$ Sedang & 61 & 40,1 \\
\hline Total & 152 & 100 \\
\hline
\end{tabular}

Tabel 2. Analisis Bivariat

\begin{tabular}{lccccccc}
\hline $\begin{array}{c}\text { Aktivitas } \\
\text { fisik }\end{array}$ & \multicolumn{3}{c}{ IMT } & Total & $\begin{array}{c}\text { p } \\
\text { value }\end{array}$ \\
\cline { 2 - 6 } & $\begin{array}{c}\text { Gizi } \\
\text { normal/ } \\
\text { kurang }\end{array}$ & $\begin{array}{c}\text { Gizi } \\
\text { lebih }\end{array}$ & & & \\
\cline { 2 - 7 } & $\mathbf{n}$ & $\mathbf{\%}$ & $\mathbf{n}$ & $\mathbf{\%}$ & $\mathbf{n}$ & $\mathbf{\%}$ & \\
\hline Ringan & 70 & 76,9 & 21 & 23,1 & 91 & 100 & \\
Sedang & 56 & 91,8 & 5 & 8,2 & 61 & 100 & 0,03 \\
Jumlah & 126 & 82,9 & 26 & 17,1 & 152 & 100 & \\
\hline
\end{tabular}

Berdasarkan tabel 1 pada analisis univariat dapat diketahui bahwa sebagian besar responden berasal dari kelas VII (37,5\%), berjenis kelamin perempuan $(67,1 \%)$, berusia 14 tahun $(36,2 \%)$, memiliki status gizi normal/ kurang $(82,9 \%)$ dan memiliki tingkat aktivitas fisik ringan (59,9\%). Pada tabel 2 analisis bivariat diperoleh nilai pvalue $=0,03$.

\section{Pembahasan}

\section{Prevalensi IMT Pada Siswa SMPN 1 Padang}

Pada penelitian ini didapatkan persentase gizi normal/ kurang pada siswa SMPN 1 Padang sebanyak $82,9 \%$ dan gizi lebih sebanyak $17,1 \%$. Hasil ini sesuai dengan penelitian yang dilakukan oleh Syahfitri, Ernalia dan Restuastuti (2016) di SMPN 13 Pekanbaru, didapatkan hasil bahwa siswa memiliki status gizi tertinggi yaitu gizi normal sebanyak 59\% sedangkan gizi sangat kurus sebanyak $1 \%$, gizi kurus sebanyak $7 \%$, gizi gemuk sebanyak $3 \%$ dan obesitas sebanyak $10 \%$.
Metode penelitian yang dipakai memiliki persamaan pada pemilihan kriteria inklusi dan eksklusi, cara pengumpulan data dan cara mengkategorikan status IMT berdasarkan peraturan Kemenkes RI. ${ }^{17}$

Hasil yang sama ditemukan pada penelitian Hendrayati, Salmiah dan Rauf (2010) di SMP Negeri 4 Tompobulu, didapatkan hasil bahwa status gizi siswa umumnya normal $(85,4 \%)$, siswa sangat kurus sebanyak $1 \%$, siswa yang overweight dan obesitas masing-masing sebanyak 2,1\%. Penelitiannya memiliki persamaan pada metode penelitian yaitu menggunakan metode pendekatan cross sectional, sampel siswa usia 1215 tahun dan jenis peneliannya analitik. ${ }^{18}$

Hasil berbeda ditemukan pada penelitian Pangow, Bodhi dan Budiarso (2019) di SMPN 6 Manado, didapatkan hasil bahwa status gizi siswa umumnya kurus (57\%) sedangkan status gizi normal 34\%, gizi lebih $4 \%$ dan obesitas sebanyak 5\%. Penelitiannya memperoleh hasil yang berbeda karena cara mengkategorikan IMT menggunakan batas ambang IMT untuk Indonesia. ${ }^{19}$

Pada penelitian ini status IMT normal/ kurang menjadi nilai tertinggi (82,9\%), selebihnya mengalami gizi lebih $(17,1 \%)$. Status IMT yang normal dapat terjadi apabila tubuh seseorang cukup memperoleh zat gizi yang digunakan secara efisien sehingga memungkinkan pertumbuhan fisik, perkembangan otak dan kemampuan kerja mencapai tingkat optimal. Gizi lebih sering terjadi karena asupan energi lebih besar dan aktivitas fisiknya kurang serta kerentanan genetik. ${ }^{20}$

\section{Tingkat Aktivitas Fisik Pada Siswa SMPN 1 Padang}

Tingkat aktivitas fisik pada penelitian ini diukur dengan wawancara menggunakan kuesioner aktivitas fisik indeks Baecke. Pengukuran tingkat aktivitas fisik dalam kuesioner indeks Baecke merupakan penjumlahan dari indeks waktu kerja, olahraga dan waktu luang. Pada penelitian ini dapat diketahui bahwa sebagian besar responden memiliki tingkat aktivitas fisik ringan yaitu $59,9 \%$ sedangkan sisanya 40,1\% memiliki tingkat aktivitas fisik sedang. Hasil penelitian sama yang dilakukan Sari, Ernalia dan Bebasari (2016) didapatkan hasil sebanyak 52\% siswa melakukan aktivitas ringan dan 48\% siswa melakukan aktivitas sedang. Hasil 
penelitian sama didapatkan karena memiliki persamaan pada jenis penelitian, desain penelitian dan usia responden, tetapi koesioner yang digunakan adalah kuesioner IPAQ. ${ }^{21}$

Aktivitas fisik yang kurang menyebabkan banyak energi yang tersimpan sebagai lemak, sehingga orang yang kurang melakukan aktivitas fisik cenderung menjadi gemuk. Anak yang beraktivitas fisik ringan berhubungan bermakna terhadap berat badan lebih. ${ }^{22}$ Tingkat aktivitas rendah memicu terjadinya penurunan metabolisme basal dan sebaliknya. Keadaan ini menyebabkan terjadinya peningkatan simpanan energi dalam lemak sehingga memicu peningkatan jumlah dan ukuran sel lemak dalam tubuh. $^{23}$

Kesimbangan energi bisa terjadi bila asupan energi sesuai dengan energi yang digunakan untuk melakukan kegiatan. Energi yang digunakan tergantung kepada jenis pekerjaan dan aktivitas yang dilakukan sehari-hari. Bila asupan energi lebih besar dari energi yang dikeluarkan dan berlangsung lama, akan terjadi akumulasi lemak tubuh yang tercermin dari IMT yang tinggi. ${ }^{23}$

\section{Hubungan Aktivitas Fisik Dengan IMT Pada Siswa SMPN 1 Padang}

Pada penelitian ini dilakukan analisis antara aktivitas fisik dengan IMT pada siswa SMPN 1 Padang. Berdasarkan uji chi-square didapatkan hubungan yang signifikan antara aktivitas fisik dengan IMT $(p=0,03)$. Hasil yang sama juga ditemukan oleh Putra dan Rizki (2018), menggunakan perhitungan uji korelasi dengan chi-square diperoleh signifikan sebesar 0,043. Penelitiannya memiliki persamaan yaitu menggunakan studi analitik dengan jenis studi observasional dengan pendekatan cross sectional. Populasi dalam penelitian adalah siswa usia 13-15 tahun di SMPN 1 Sumber Lawang. Terdapat perbedaan dari sampel yang diambil dengan teknik total sampling. Aktivitas fisik dinilai dengan metode recall, kemudian mengelompokkan intensitas menjadi tiga tingkatan menurut nilai METs yaitu intensitas ringan, sedang dan berat. ${ }^{24}$

Hasil penelitian berbeda ditemukan pada penelitian Saint (2019), penelitian ini menggunakan metode observasional analitik dengan rancangan cross sectional. Status gizi diperoleh dari pengukuran berat badan dan tinggi badan sedangkan aktivitas fisik menggunakan pengisian koesioner International Physical Activity Questioner (IPAQ). Sampel penelitian sebanyak 123 responden dengan usia responden diambil dari usia 14-18 tahun. Dari hasil pengujian menggunakan person chi-square didapatkan bahwa tidak terdapat hubungan yang bermakna antara aktivitas fisik dengan status gizi $(p$-value $=$ 0,892). ${ }^{25}$

Meskipun terdapat persamaan dalam metode, rancangan penelitian dan tes uji chi-square pada penelitian ini, namun tidak dapat menunjukkan adanya perbedaan bermakna. Hal demikian dikarenakan mayoritas responden penelitian di SMPN 1 Padang memiliki status gizi normal/ kurang. Aktivitas fisik merupakan salah satu faktor yang mempengaruhi status gizi. Semakin ringan intensitas aktivitas fisik yang dilakukan maka berpengaruh terhadap status gizi (IMT/U) lebih bahkan obesitas. ${ }^{26}$

\section{Simpulan}

Sebagian besar siswa memiliki IMT yang normal/kurang, memiliki tingkat aktivitas fisik ringan dan terdapat hubungan yang bermakna antara aktivitas fisik dengan IMT pada siswa SMPN 1 Padang.

\section{Ucapan Terima Kasih}

Terima kasih penulis sampaikan kepada SMP Negeri 1 Padang yang telah membantu pelaksanaan penelitian ini dan pihak terkait yang terlibat selama penelitian ini.

\section{Daftar Pustaka}

1. Kesmas. Metode penentuan status gizi dengan antropometri. Public Health Home. 2016. Diakses dari www.indonesian-publichealth.com/metodepenentuan-status-gizi-dengan-antropometri/. Tanggal 28 Juli 2020.

2. Aulia KA, Reviono, Yudhani RD. Perbedaan kualitas tidur pasien asma terkontrol sebagian pada kategori Indeks Massa Tubuh (IMT). Smart Medical Journal. 2019;2(1):38-49.

3. Rahayu NP. Indeks massa tubuh mempengaruhi kesehatan. Intisari Online. 2013. Diakses dari https://intisari.grid.id/tag/imt.Tanggal 28 Juli 2020.

4. A YK, D YLR, Wekadigunawan CSP. Path analysis of the psychosocial impact of obesity or overweight in adolescents in Surakarta, Central Java. Journal of Epidemiology and Public Health. 2018;3(2):105-17.

5. Spieker EA, Pyzocha N. Economic impact of obesity. Primary Care: Clinics in Office Practice. 2015;43(1):83-95.

6. Hales CM, Carroll MD, Fryar CD, Ogden CL. Prevalence of obesity among adults and youth: the United States, 2015-2016. 2017. 
7. Niehues JR, Gonzales AI, Lemos RR, Bezerra PP, Haas $P$. Prevalence of overweight and obesity in children and adolescents from the age range of 2 to 19 years old in Brazil. International Journal of Pediatrics. 2017. $\mathrm{Hal}$ 2. http://dx.doi.org/10.1155/2014/583207.

8. Pengpid S, Peltzer K. Underweight and overweight or obesity and associated factors among school-going adolescents in five ASEAN countries, 2015. Diabetes \& Metabolic Syndrome: Clinical Research \& Reviews. 2019; 13 (6): 3076.

9. Kemenkes RI. Laporan nasional riskesdas 2018 [Internet]. Badan Penelitian Dan Pengembangan Kesehatan. 2019 [cited 2019 Dec 2]. p. 1-674. Available from: http://labmandat.litbang.depkes.go.id/images/down load/laporan/RKD/2018/Laporan_Nasional_RKD20 18_FINAL.pdf.

10. Putra RNY, Ermawati, Amir A. Hubungan Indeks Massa Tubuh (IMT) dengan usia menarche pada siswi SMP Negeri 1 Padang. Jurnal Kesehatan Andalas. 2016;5(3):551-7.

11. Premayani I, Dewantari NM, Sudjana IDN. Hubungan aktivitas fisik dengan Indeks Massa Tubuh pada remaja. Jurnal Ilmu Gizi. 2014;5(1):30-4.

12. Kemenkes. Mengukur status gizi dengan Indeks Massa Tubuh [Internet]. Vol. 2. 2011 [cited 2020 Mar 3]. p. 1-4. Available from: http://staffnew.uny.ac.id/upload/132318122/pendi dikan/BAHAN+AJAR+IMT.pdf.

13. IDAI. Diagnosis, tatalaksana dan pencegahan obesitas pada anak dan remaja [Internet]. Ikatan Dokter Anak Indonesia. 2014. p. 1-64. Available from: http://www.idai.or.id/professional-

resources/guideline-consensus/diagnosis-tatalaksana-dan-pencegahan-obesitas-pada-anak-danremaja.

14. Pradana A. Hubungan antara Indeks Massa Tubuh (IMT) dengan nilai lemak viseral. Jurnal Media Medika Muda. 2014;1-19.

15. Rogers LQ, Carter SJ, Williams G, Courneya KS Concepts and definitions are relevant to physical activity and exercise [Internet]. Springer Nature. 2018 [cited 2020 Mar 5]. p. 287-307. Available from: https://link.springer.com/chapter/10.1007/978-3319-77432-9_15.

16. Piercy KL, Troiano RP, Ballard RM, Carlson SA, Fulton JE, Galuska DA, et al. The physical activity guidelines for Americans. Journal American Medical Association. 2018;320(19):2020-8.

17. Syahfitri Y, Ernalia Y, Restuastuti T. Gambaran status gizi siswa-siswi SMP Negeri 13 Pekanbaru tahun 2016. Jurnal Online Mahasiswa Fakultas Kedokteran. 2017;4(2):1-12.

18. Hendrayati, Salmiah, Rauf S. Pengetahuan gizi, pola makan dan status gizi siswa SMP Negeri 4 Tompobulu Kabupaten Bantaeng. Media Gizi Pangan. 2010;9(1):33-40.

19. Pangow S, Bodhi W, Budiarso F. Status gizi pada remaja SMP Negeri 6 Manado mengunakan indeks massa tubuh dan lingkar pinggang. Jurnal Biomedik. 2020;12(1):43-7.

20. Indra D, Wulandari Y. Prinsip-prinsip dasar ahli gizi. Edisi ke-1. Jakarta: Dunia Cerdas. 2013. Hal 11-14.

21. Sari AM, Ernalia Y, Bebasari E. Hubungan aktivitas fisik dengan kejadian obesitas pada siswa SMPN di Pekanbaru. Jurnal Online Mahasiswa Fakultas Kedokteran. 2017;4(1):1-8.
22. Mujur A. Hubungan antara pola makan dan aktivitas fisik dengan kejadian berat badan lebih pada remaja. Jurnal Online Mahasiswa Fakultas Kedokteran. 2011;3(1):29-32.

23. Layli AN. Obesitas dan keseimbangan energi. Artikel Ilmu Gizi. 2019. Diakses dari http://repository.stikessurabaya.ac.id/admin/items /show/36. Tanggal 24 Juli 2020.

24. Putra YW, Rizqi AS. Index Massa Tubuh (IMT) mempengaruhi aktivitas remaja putri SMP Negeri 1 Sumberlawang. Jurnal Ilmu Kesehatan. 2018;16(1):105-15.

25. Saint HO, Ernawati. Hubungan aktivitas fisik dengan status gizi pada siswa $X$ dan XII IPA SMAN 7 Surakarta periode 2017 / 2018. Tarumanagara Medical Journal. 2019;2(1):54-8.

26. Inggrid C. Hubungan antara aktivitas fisik dengan status gizi pelajar SMP Frater Don Bosco Manado. Jurnal Ilmu Kesehatan. 2012;14(1):115-120. 